\title{
Author's Response: The Question of Dharmic Coherence
}

\section{Rajiv Malhotra}

I greatly appreciate the thoughtful essays on my book in this issue and welcome the opportunity to respond to them. At the outset I wish to point out that three of the essays (those by Nicholas F. Gier, Gerald James Larson and Robert A. Yelle) explicitly assume that Being Different's position depend on Advaita Vedānta and that I regard the world as an illusion. Both assumptions are incorrect. My project rejects such common stances about Hinduism for a variety of reasons: Either they are too limiting and apply only to one narrow school (such as Advaita Vedānta), thereby making it impossible to have a broader dharmic worldview from where to gaze at the West. Or they are too broad and end up encompassing all religions, including Western ones. I am seeking something in between these poles.

Rather than nitpicking each issue in the essays, I have identified four broad areas where the six authors have highlighted some concerns, and will address each in a separate section. Section One addresses the variety of methodological issues raised concerning the very nature of my project, which is to present a dharmic view of the West and highlight the contrasts between the two civilizations. Section Two defends one of the core theses of the book, namely, that there is such a thing as a unified dharmic gaze despite serious internal differences and diversity among the schools and sub-schools. This section includes a pivotal discussion on the non-translatable term "mithyā." Section Three defends the charge that Western Civilization lacks the same kind of unity as Dharma and that its unity is

International Journal of Hindu Studies 16, 3: 369-408

(C) The Author(s) 2013. This article is published with open access at Springerlink.com

DOI 10.1007/s11407-012-9132-0 
of a different kind. Section Four comes to the heart of what I feel the authors of the essays in this issue, and my critics elsewhere, are deeply concerned about, even when they are not saying it explicitly: They disapprove of the very existence of a "dharmic" family, whereas my project depends upon the coherence of such a unity. Finally, Section Five addresses a few additional issues.

\section{The Methodological Challenges of Reversing the Gaze}

India is an amazingly fertile crucible. It has been the birthplace of the largest number of modern faiths outside the Abrahamic religions. This makes India as important as the Middle East in the study of humankind. And India is no simple place to understand. Just as there are immense differences among the Abrahamic religions at the same time that they share deep-rooted common assumptions and historical links, so also the faiths born in India have commonalities as well as differences. My project is to look for axiomatic contrasts between the Western and Indian families, keeping in mind that each is vast, old, robust, internally diverse and philosophically profound. In this context, the notion of family is that of a statistical cluster consisting of distinct members. Each cluster has meaningful internal commonalities that separate it from other clusters for the purpose of such an analysis.

In many comparative studies, the baseline view of Dharma generally tends to highlight caste discrimination and other human rights abuses (which no doubt need to be studied separately as topics in their own right) and present these in contrast with Western "rationality," "progress," "freedom" and the like. Of course, dharmic societies and cultures can be criticized along several lines with great validity, but as a basis for gazing at the West, this is not the most productive starting point.

Robert A. Yelle acknowledges that the preponderance of such comparisons and the relative marginalization of the dharmic perspectives in Western discourse make it necessary for an extensive critique of Western religions through the Dharma lens. Yet he strongly disagrees with my approach and calls for an approach based on "a shared humanity." Gerald James Larson also notes that Being Different does not attempt to make a neutral comparison between Indian and Western civilizations, but rather articulates difference from an explicitly dharmic position. 
Given the conditioning to which all human beings are susceptible, I do not believe that a truly neutral position is genuinely possible, let alone practical. The scholars' aspiration toward a "neutral" gaze is especially suspect when the comparisons they make employ Western hermeneutics and categories, regardless of the intentions. We know of many universal claims made by Westerners in the past. To give just a few examples: The conquistadors claimed a universal gaze bestowed on them by God with regard to their view of Native Americans. The Europeans claimed to be the keepers of "a shared humanity" in their justification of black slavery, Native American genocide, and Indian colonization. The fascism that emanated from G.W.F. Hegel (and culminated in Hitler's Auschwitz) resulted from his "universalism" and was justified as being in the best interest of the "World Spirit." We have been there before!

Bias is inherent in any "gaze from somewhere" as opposed to a "gaze from nowhere" (a position claimed by many postmodernists). The dialogue I seek is a process of challenge and response in which civilizations engage in pūrvapakșa and uttarāpakșa with one another, in an atmosphere of equality, and without pulling their punches. It is time for the native to talk back in his own terms and be prepared to face the charge of "essentialism." Such talking back is imperative if we are to evolve towards a multipolar world in which the present-day West becomes one of the provinces but not the center.

\section{Provocative Agenda}

Being Different posits that diverse dharmic schools share a core set of differences from Western universalism, and hence these dharmic schools comprise a family. It sequentially examines specific aspects of Western traditions, and illustrates how Dharma differs in areas such as: the separation of smrti from śruti, the contextual nature of smrti, the complete absence in Dharma of a central corporate authority that is equivalent to the Church, and the special status accorded to enlightened masters of Dharma traditions during their lifetime. Such "otherizing" of the West is the pürvapakșa methodology of identifying a common dharmic substrate without essentializing Dharma into any categorical definition in absolute terms.

Being Different intends to provoke. Rather than merely teaching the current state of play in the discourse, it seeks to change the discourse 
itself. This opens the door for new scholarship in which followers of Dharma would be able to participate from the perspective of their own conditioning and experiences.

\section{Avoiding Epistemic Relativism}

Rita Gross is critical of this confrontational stance. It is both unnecessary and problematic, she argues, because very few people suffer from the rhetoric of "sameness." (In other words, she implies that people already appreciate the differences, making such a project unnecessary.) My own experience with Hindu leaders, however, is that they are very keen to promote sameness. They imagine that they are doing a favor to Christians by calling Jesus an avatāra; to Muslims by singing "Īśvar Allāh tere nām" ("İ́var and Allāh are names of the same one"; which orthodox Muslims consider blasphemous); and to Buddhists by claiming that Buddhism is a part of Hinduism with Buddha as the latest avatāra of Lord Viṣnu. On the Christian side, this sameness syndrome afflicts not only a large number of well-meaning laypeople (such as those who call themselves Spiritual But Not Religious), but also the work of many scholars including Huston Smith, John Hick and the perennialists. (While it has become fashionable in the academy to accuse Svāmi Vivekānanda and other "Hindu nationalists" for "inventing modern Hinduism," the role of Western enthusiasts such as the perennialists is not adequately discussed.)

Gross criticizes Being Different for not letting "others be different without regarding different systems as less cogent than one's own." Here I wish to distinguish between mutual respect (which I espouse) and mutual agreement (which I do not espouse as the starting point): I can respect you even when I disagree with you. I respect your right to believe what I may have rejected for myself. And I make no attempt to convert you or denounce you for your beliefs on the basis of some kind of moral suasion or a priori assumption of my superiority. But I am not an epistemic relativist who feels that all truth-claims are equally true. In reversing my gaze, therefore, the other side appears to me exotic and/or incoherent in many ways. I do not think mutual respect forecloses the argument for or against the cogency or truth value of propositions, though interfaith dialogue must go beyond the propositional level to the experiential level and to the recognition that much lies beyond language and metaphysics. 
Therefore, I disagree with Gross's statement that the long-term relations between different faiths and cultures are not fostered through the process of debate.

She advocates "developing empathetic understanding of those who are very different from oneself than by debate about whose position is superior." However, she does not elaborate how this "empathic understanding" is to be achieved without first debating and arguing propositions and truth-claims with an open mind. Being Different is clearly going beyond the laissez-faire attitude that says, "You have your point of view and I have mine."

The West itself stands to gain a great deal from being gazed at by an external lens-just as a psychologist's external lens can provide the client with new insights into himself. The Dharma family of worldviews is arguably the most sophisticated outside the West which can lend itself to the purpose of providing an external critique. Such an external gaze is never comfortable.

\section{Prior Attempts are Inadequate}

Yelle rightly makes the point that Indian postcolonial scholarship already reverses the gaze on the West. But he fails to note that most such scholars have adopted Western theories and vocabularies (in part presumably because they depend on Western funding and institutions for their careers), and that they often simply lack adequate knowledge of and sympathy with their own native siddhānta (theories) to use as an alternative point from which to launch their critique. Their criticisms of the West do not qualify as legitimate pürvapakșa through dharmic lenses in the sense that I am speaking of; rather they should be seen as part of the Western tradition of self-critique. This critique, I appreciate, is quite extensive and useful, but it is not a substitute for critiques rooted in a non-Western axiomatic system.

I am aware of scholarship that uses categories indigenous to India (for example, A.K. Ramanujan, McKim Marriott and Ronald Inden), but such scholarship has only looked at India—not back at the West. To decolonize oneself by looking at oneself through one's native categories is a necessary first step, but it is not sufficient if the goal is to bring these categories into play in the global discourse. One's lens must also be able to offer new insights into other cultures, thus inspiring alternative modes of thinking. 
That is where Being Different seeks to extend the conversation.

As referenced in Being Different, one work that does go in this direction using Buddhist terms is David Loy's study of Western civilization. He looks at the West in terms of its profound sense of lack, which he compares to the Buddhist sense of dukkha. There are also intimations of this reversal of the gaze in the thought of M.K. Gandhi (for example, his seminal "Hind Swaraj" written a century ago) and Śrī Aurobindo. They have been profound catalysts for my own thought, and I believe they and others like them could be re-visited.

I locate Being Different alongside the works of Christian theologians Raimundo Panikkar and Jacques Dupuis. Their works compare and contrast the same entities that Being Different addresses. Yet, unlike Yelle's criticism of Being Different, there is no charge alleging these scholars to have essentialized Dharma, or to have ignored the existence of social problems within Christianity (which is their faith), or to have put forward a reductionist representation of Christianity. Nor have these scholars made any attempt to conceal their explicitly Christian standpoint. Yet their scholarship has never been criticized on the basis that they did not maintain "neutrality." They faced the same methodological challenges as I do, in terms of determining a precise level of abstraction within which to frame their arguments and in selecting the characteristic features of Hinduism and Christianity that were sufficiently wide as to underpin a meaningful comparative exercise. Similar exercises from a dharmic perspective, and employing a parallel methodology, should therefore be encouraged. My book is a start in that direction.

\section{Dharma's Integral Unity}

When a dharmic lens is offered as a strong and relatively unified perspective, one faces a huge outcry from those parts of the academy that have assumed the role of mediator between Dharma and the West. This outrage, implicit in many of the essays in this issue, often takes the form of the charge of essentialism.

Yelle and Larson in particular make this claim, and Cleo Kearns also notes that I seem to be reinstating a binary dynamic and thus freezing debate. Gier asserts that Being Different claims an Indian universalism, and writes: "An Indian universalism would be just as problematic as the 
Euro-American variety has been." However, Being Different does not propose an alternative universalism. I clarify at the outset that I employ Dharma as a foil against which to pose its view of Western Universalism. The technique of gaze reversal does not necessarily imply that the one who is now gazing is making his own claim to universalism. I reject any universalism, be it of an American, European or Indian variety.

Larson seeks to preempt the gaze reversal by undermining the coherence of a positive sense of Dharma. We clearly hold opposing views on the question of whether there is a dharmic civilization that is characterized by coherence and integral unity. Larson contends that any assertion of dharmic unity must necessarily impose homogeneity. I will explain below why Larson is incorrect.

\section{Integral Unity is Not Homogeneity}

Being Different's position is that multiple Dharma systems can each have integral unity and yet have different and even incompatible metaphysics. The fact that each has integrality and yet is distinct from the rest is akin to several different objects being yellow-that is, the common quality of yellowness gives a family resemblance without making all the yellow objects the same. A more direct analogy is as follows: Judaism, Christianity, and Islam share the characteristic of reliance upon historical prophets, without all the prophetic revelations being homogeneous. Their family resemblance is that prophetic revelations in history are the ultimate means to access religious truth, and yet there is immense diversity within the family. One could identify the very distinct systems of Judaic, Christian, and Islamic prophetism; one might even discern sub-branches such as Mormon and Ahmaddiya prophetism. Gier's criticism that Being Different somehow reduces all Indian belief systems into a single homogeneity is equivalent to an argument that by demonstrating the differences between Judaism and Christianity, one claims to have debunked their shared principle of prophetic revelation.

An integral unity, likewise, may be expressed through Mādhyamika, Advaita, Viśișțādvaita, Tantra, Aurobindo and many other forms, each of which is distinct. Being Different goes to great lengths to explain that different Dharma systems disagree on many key points, yet each adheres to the common standard of integral unity proposed in the book.

Yelle is right when he says that, "Every tradition is in fact an amalgam, 
and retains the traces of its composite origins." But he is wrong when he argues against my use of common features such as integral unity and embodied knowing, calling these "a thoroughly modern and homogenized ideal of Hinduism drawn from certain aspects of Vedānta philosophy and Yoga." His concern about homogenization would have been legitimate if Being Different had proposed an integration of all Dharma traditions into a single new tradition. This is simply not my goal. Looking for commonality as a standpoint from which to gaze at a different family does not require us to relinquish the internal distinctiveness among the members of either family.

In summary, integral unity differs from homogeneity by two cardinal criteria. First, integral unity does not mandate that any integral system need be homogeneous internally, and in fact the integral unity itself implies built-in multiplicity of certain kinds. This invalidates the claims that I advocate undifferentiated unity. Second, integral unity does not imply that every integral system must be in agreement with every other integral system on all matters. This invalidates the claim that I represent all Dharma systems as being the same.

\section{Charge of Fragmentation}

Once the reader is convinced that there is merit in a Dharma-specific gaze at the West, then it follows that we need a coherent dharmic place from which to start. For if Dharma is a mere random scattering of incoherent exotica, there could be no such place from which gazing at the West would be feasible. The concept of the "West" as a unified entity has been made very robust over a long time, despite recent attempts by postcolonialists to deconstruct it. On the other hand, Dharma is portrayed as internally fragmented, divisive and oppressive, to such an extent that it is made to appear that it lacks any coherent position that is worthy. Hence the very ground from which one might offer a dharmic gaze is depicted as shaky and fabricated.

Though Larson also makes this charge of fragmentation, it is Gier who takes the lead. He writes: "Malhotra himself admits that there are "profound differences in theory and practice' in the Dharma traditions, so this undermines his principal claim that these philosophical schools are 'integral'." Gier's misinterpretation, here, arises from his having confused "integral" with "homogeneous," a point I have already clarified earlier. 
Larson argues that the refutation of permanent substance by Buddhist cosmology undermines the notion of integral unity. But Being Different explains how Mādhyamika Buddhism has integral unity even though its version differs from Hindu schools. Appendix A in Being Different elaborates the applicability of certain Dharma tenets across a variety of traditions, including Mādhyamika, Jaina, Tantra and Kashmir Śaiva. Larson seems to have assumed that integral unity is a theistic notion, and thus ignores my conscious definition of the term for applicability to either theistic or non-theistic contexts. Moreover, in the course of his critique, Larson attempts to support his argument by offering an interpretation of Nāgārjuna that verges on nihilism; in so doing, he illustrates precisely the sort of reductive trap that Being Different seeks to avoid.

To support his position that Patañjali's system is not integral, Gier cites statements by Western authors who claim that the meditation techniques it employs are Buddhist. However, several Buddhist scholars affirm that Buddha himself used numerous techniques practiced by Sanātana Dharma as stepping stones to achieve his nirvanna. Evidently, Gier is trying to strengthen his thesis that cross-borrowings among Indian schools are of the same synthetic variety as the cross-borrowings that occurred between Hebraic and Hellenistic systems. This, of course, completely ignores the bitter legacy of historical tensions and philosophical contradictions between Hebraism and Hellenism: a syndrome characteristic of synthetic unity. Being Different discusses this point at length. In one particularly abstruse passage Gier writes: "Malhotra notes that Buddhism understands unity 'in a radically different way than in Vedānta.' If this is so, then Buddhism cannot be considered a 'constituent or component' of Vedānta." However, nowhere have I ever attempted to construe Buddhism as a constituent or component of Vedānta.

In his desire to present Indian civilization as fragmented, Gier writes, "Contrary to all the Indian schools, the Buddha ...," thus implying that Buddhism is somehow non-Indian. Indeed, it is common among some Western scholars to emphasize a de-Indianized Buddhism and to focus on the mutual tensions, rather than the synergy, between Hinduism and Buddhism. Clearly, Gier's insistence that the traditions of India cannot be seen as unified at any level reinforces my contention that the Western lens is programmed to look for incoherence in Indian civilization. Assertions of dharmic coherence are therefore considered troubling. 


\section{Mistranslation and Misunderstanding of Mithyā}

A major problem with Gier's position, as with many modern interpretations of Dharma, concerns a persistent mistranslation and misunderstanding of the word mithya . As used in the context of Vedānta, mithya is often wrongly translated as "illusion." Similarly, the words sat and asat are respectively mistranslated as "real" and "unreal." This, in fact, reflects a limitation of the English language in failing to allow for a category that is between "real" and "unreal."

Such a limitation precipitates the conflation of asat and mithya (both being mistranslated as "unreal"), making it impossible to conceive of mithya $\bar{a}$ as a type of reality different than either sat or asat. This seriously flawed understanding of basic Vedānta terminology has fed the misconception that Śankara regards the world as illusory, which in turn feeds the stereotype of a worldview predicated on otherworldliness, social irresponsibility, fatalism and the like.

It is this very misconception which causes Gier to conclude that, "If Malhotra believes that organic unity of self, cosmos and God is essential to the Dharma tradition, then Śankara does not meet that criterion." Gier makes this sweeping statement relying unduly upon Lance Nelson's secondary scholarship. He states: "Nelson contends that Advaita Vedānta achieves its non-duality 'exclusively not inclusively' such that disunity rather than unity with the world is the result.... Nelson shows that the Advaitin imputes no value whatsoever to the natural world and by implication, none to the social world either" (emphasis added). Gier cannot claim to effect a dismissal of such magnitude simply through a casual citation, while failing to provide a single substantive argument of his own in support.

Kristen L. Southworth in "Hindu Worldview and Ecological Engagement" (2010) vehemently disagrees with Nelson's "world negating" homogeneity theory of Vedānta. She writes:

Lance Nelson has tried to make a strong argument that the Advaita Vedanta tradition, which has been dominant both in numbers and prestige for more than 1000 years, "encourages attitudes of devaluation and neglect of the natural universe."

Yet Nelson seems to confuse ideas that ascetic monks commit themselves to in order to reach a state of liberation with a description of the 
nature of liberation. In other words, he confuses the means with the end. His criticisms are centered on textual examples of exercises that are meant to encourage disgust towards all things worldly among practicing ascetics. For the ascetic monk seeking pure Selfhood, a process of total renunciation is indeed needed. But these are not practices intended for everyone, nor are they doctrines describing the character of liberation. We might note here, as well, that this process of worldly denial in order to gain spiritual maturity is certainly not unique to Hinduism.

In fact, within Christianity we find some of the most striking theological rejections of "this world," along with a focus on a resurrected life in another world. For many, resurrection is representative that the end goal is the afterlife, and this has become the most central tenet of the faith for many people, one which has given rise to a consistent ethical dilemma throughout Christian history: why should I work to improve conditions in this world when my home is ultimately elsewhere? In many popular Christian cosmologies, this "other world" is seen as utterly elsewhere, entirely separate from this world. As such, ascetic monks and lay Christians alike have, throughout history, struggled to find the motivation to engage in restorative social efforts that bring about positive change in this world. I think we should be very careful about applying the same cosmology of salvation, and thus the same problem, to Hinduism (Southworth 2010: 4).

The conception of reality in Vedānta is always comparative. Relative to a particular material, an object made out of that material is considered "less real." For example, a bucket made out of plastic is unreal relative to the plastic itself. This is elucidated in the Chāndogya Upanisad (6.1.4) which explains that a clay pot is in fact name-and-form (nämarūpa) taken on by clay, so that the clay pot is not real, independent of the clay. A cause is thus considered to be "more real" than its effect, because the reality of an effect depends upon its cause. It follows that anything which has a material and/or efficient cause can be described as mithyā: a dependent reality. The "cause of the world" is thus ascribed a greater degree of reality than the world itself. When we say that the universe is mithya $\bar{a}$, we mean that it is unreal when seen as an independent reality; however, it is surely real when seen as brahman, its cause. 
Śañkara's Bhāṣya on Bādarāyaṇa's Brahmasūtra is an important source on this matter, arguing that

omniscient and omnipotent source must be brahman from which occurs the birth, continuance, and dissolution of this universe that is manifested through name and form, that is associated with diverse agents and experiences, that provides the support for action and results, having well-regulated space, time and causation, and that defies all thoughts about the real nature of its creation (1.1.2; Svāmi Gambīrānanda's translation).

As this should clarify, Śankara does not describe the universe as being anything even remotely close to illusory; indeed, it is the organic unity encompassing the Universe, its diverse agents, and its experiences that Śankara terms brahman. This excerpt also indicates what Śankara means by mithyā: "that [which] defies all thoughts about the real nature of its creation." Svāmi Bhajānanda explains it as follows:

The Advaitin concludes that the world is different from both sat and asat; it is sad-asad-vilakșana. Such a fact defies the laws of [ordinary] logical thinking; hence, it is anirvacaniya. Another word used in the same sense is mithya $\bar{a}$. In common parlance mithya means illusion or falsehood, but in Advaita Vedanta it means something "mysterious" (2010: 6).

To understand mithya correctly in relation to sat and asat, one must appreciate that sat is that which does not depend upon anything else for its existence, mithy $\bar{a}$ is that which depends upon something else for its existence and asat is that which cannot have existence. The profound points of distinction between these Sanskrit terms become blurred by mistranslation into Western languages that simply cannot support the categories they wish to appropriate, leading ultimately to distortions such as those provided by Nelson and reproduced by Gier.

\section{Integral Unity in Systems other than Advaita Vedānta}

Rāmānuja's Viśișțādvaita, which is distinctively different from Advaita, ultimately also presents a view of the universe predicated on integral unity 
as defined in Being Different. To understand Viśișțādvaita accurately, one must first appreciate the specific contours of Rāmānuja's approach. In contrast to Śankkara, Rāmānuja maintains that brahman cannot be imagined as nirguna or nirviśeșa (devoid of attributes). In support of this, he divides Vedic passages into two categories: abheda-śruti, passages that negate difference, suggesting that brahman is without any internal distinctions (examples are Chāndogya Upanișad 3.14.1; Māndūkya Upanișad 3.2), and bheda-śruti, passages that uphold difference, suggesting that internal distinctions exist within brahman (Śvetāsvatara Upanișad 1.9; Kaṭa Upaniṣad 2.2.13).

Rāmānuja does not consider these two categories as contradicting each other; indeed, he declares emphatically that both are true. The apparent contradiction between them is resolved and harmonized by another category called ghațaka-śruti, exemplified by the antaryāmi brahma passage of the Brhadāranyaka Upanișad which explains that all sentient and nonsentient beings relate to brahman in the same manner as the body relates to the indweller; a relationship it calls pradhāna-pratitantram. Rāmānuja emphasizes Bṛadāranyaka Upanișad 3.3-22 in order to establish the true nature of the three tattvas-iśvara (Lord), cit (consciousness) and acit (matter) - that form an integral unity called śarìra-śarìri (body-indweller). The essence of śarìra-śarìri doctrine is that while śarìra and śarīri are real, śarìra depends inseparably upon śarìri. Just as the physical body inseparably depends upon śarìri, so cit depends inseparably upon îsvara for its existence. Brahman alone is ultimately independent. Integral unity, therefore, is clearly established and upheld in the precepts of Viśiștāadvaita. Thus, the systems of Śankara and Rāmānuja are each characterized by integral unity, albeit in different ways and despite other major disagreements between them. Śankara's system proposes the integral unity by explaining that mithy $\bar{a}$ is not a separable, self-sustaining entity, but depends upon underlying brahman for its existence. Rāmānuja, likewise, posits the integral unity of brahman as antaryāmi; a foundational quality inherent within all that exists.

Shrinivas Tilak's essay provides further arguments to support my explanation of integral unity as it applies to each of a variety of dharmic systems. For example:

(i) In the case of Hinduism, Tilak explains integrality separately in the texts of bhedābheda, Vedānta, Sāṃkhya, Vaiśeșika, Mīmāṃsā and 
Patañjali's Yogasūtra. Indeed these systems are not presented as homogeneous in Being Different, but as each possessing its own metaphysics of integrality.

(ii) He reminds us that in Buddhism there is no personal supreme being, such as brahman, ìsvara, Viṣnu or Śiva. Dyadic contrasts are avoided by emphasizing the mutual interdependence of all entities, which is Buddhism's notion of integral unity. The fundamental principle of dependent co-origination (pratītya-samutpāda) indicates that any entity or process exists in mutual relation to all other entities and processes. This web or network of causation involves relations with feedback as in systems theory and may be seen as ontological as well as epistemological. This principle is called the absence of essences (śünyatā), meaning that nothing — not an idea, feeling, emotion and certainly not a physical object-exists ultimately as a separable entity. Clearly, this satisfies the definition of integral unity whilst being different from the Hindu systems.

(iii) The Jaina idea of anekāntavāda is that a given viewpoint (naya), while legitimate in itself, cannot claim to be complete or exclude other viewpoints, even those that seem to contradict it. The Tattvārthasūtra typically divides a naya into substantial and modal, and what is affirmed from one viewpoint appears unreal from the other. Thus, from the modal perspective things necessarily originate and perish, while from a substantial perspective there is neither origination nor destruction. No "thing" can be seen in separation and isolation.

(iv) I find his suggestion that the Sikh notion of integrality may be understood through musical mode (based on rāga, tāla and ghar) as a key organization principle in the Ādi Granth most creative. He explains how this text is itself an embodiment of integrality.

After showing how a variety of separate kinds of integral unity are found in the dharmic systems, Tilak argues that the notion of integral unity may be taken a step further and applied to the relationships among the four major Dharma traditions. As one example of what they share, he demonstrates how the non-translatable categories of prajña $\bar{a}$ prāna and prapanca, among others, serve as a common denominator in diverse cognitive, metaphysical and spiritual systems that comprise and constitute these traditions.

The four Dharma systems also share these general presuppositions: They all lead to the transcendent principle expressed variously as brahman, 
nirvāna and kevala; they facilitate the attainment of an extraordinary and direct experience (such as the highest yogic samādhi), leading to the realization of the transcendent principle at the personal level (sometimes even at the embodied level as jīvanamukta or avalokateśvara); and they facilitate a harmonious relation between the phenomenal and material mode of life (samsāra) with the goal of spiritual liberation (paramārtha) variously. They all share praxis, including symbols, foods, customs, social values, sacred geography, family values, festivals and so on.

To further illustrate the point that Tilak is making, Hindus, Jainas and Sikhs would have no objection to the formulation of the nature of dharma as understood in terms of the famous Buddhist eightfold path. All would agree that it involves the following elements: prajna $\bar{a}$, correct view, intention and speech, corresponding to orthodoxy; śila, correct action, livelihood and effort, corresponding to orthopraxy; and samädhi, correct mindfulness and concentration, corresponding to yogic methodology.

Tilak goes on to explain that a given word or linguistic expression is not the monopoly of any one dharmic tradition or language. The wellestablished Vedic method of bandhuta is used to demonstrate the common ground and themes of Dharma shared by all schools. Each Dharma tradition retells anecdotes and narratives using its own symbolism, the real meaning of which lies in a truth to which the symbols point.

\section{Defending the Principle of Mantras}

While Being Different cites Sanskrit mantras as a major principle with no Western equivalent and refers to classical Indian grammarians and philosophers, Yelle rejects the notion of Sanskrit non-translatables. He calls it "a nativist ideology," "nothing more nor less than ethnolinguistic chauvinism," and dismisses it as "magical thinking." Let me first say that the philosophy of mantra non-translatability does not rest on Sanskrit being "superior" to other languages. Furthermore, Yelle makes no attempt to address the Indian classical theories of language, sound and grammar that I cite, but rather relies entirely upon Western philosophy, stating that "one of the basic premises of modern, Western views of language, at least since John Locke, is that language is arbitrary. This idea has now been firmly established, with very few exceptions, in modern linguistic science." I question his axiomatic usage of what he regards as modern linguistic "science" and Western philosophy. This confident acceptance 
of received doctrine illustrates why my project has merit, for without the ability to step outside the Western system and reverse the gaze, views such as Locke's on the nature of language would remain unchallenged.

Yelle's rejection of Sanskrit's sophisticated theory of mantras in effect also dismisses the theory of four levels of $v \bar{a} c$ that is at the heart of Kashmir Śaiva, Tantra and several other Dharma schools. The literature on this is vast. Moreover, Yelle fails to appreciate that non-translatability resists reductionism and demands "thick descriptions"-and hence sustains diversity. Nor does he bother to tackle even one of the numerous examples cited in chapter 5 of Being Different, where common translations are shown to be misleading and reductionist.

\section{Is Western Civilization Unified in the Same Manner?}

A corollary to Yelle's claim that I want internal homogeneity among the schools of Dharma, is his argument that Being Different is artificially overstating the differences between the Dharma and Abrahamic sides of the comparison:

One unstated goal of Malhotra's project seems to be to identify the socalled Abrahamic traditions-the monotheistic traditions stemming from the Hebrew Bible — as both essentially similar to each other and essentially different from dharmic traditions....In hastening to highlight the differences between Western and dharmic traditions, Malhotra frequently exaggerates those differences and neglects the many points of commonality.

This goal is, in fact, not "unstated" but explicit, for only by maximizing the distance can we have such a mutual pūrvapakșa and uttarāpakșa. There are definitely many points of commonality, but other areas of commonality have been frequently based upon misinterpretations, and Being Different offers a corrective to precisely this problem.

Kearns also criticizes Being Different along these lines, though in a slightly different way. She argues that in positing a sharp divide between dharmic and Abrahamic perspectives, I am falling into precisely the kind of binary anxiety to which Western thought is prey, rather than the "flowing, embracive, relaxed sensibility" that allows Dharma to be multiple 
without losing coherence. Indeed I have struggled with this, and concluded that the principle of skillful means is applicable here: the methodology adopted cannot be taken literally, but must be seen as a device to serve a certain purpose.

In all Dharma systems a provisional reality must be taken seriously in order to function in this world, even when the ultimate goal is to transcend it. The metaphor of the raft is often given: one must use the raft to cross the river, knowing fully well that the raft is to be abandoned at a later time. I have developed these binaries between Dharma systems and the West as skillful means to highlight the gaze from the dharmic lens that has not received its due-that is, as a corrective; and these are not intended as some kind of absolute essences. If I were to remain stuck in such binaries and not be able to move after I have clarified the dynamics between these poles, my project would indeed be self-defeating.

Being Different finds the postmodernist deconstructions of the West inadequate because they lack any coherent alternative worldview as the source of gazing. This means that after decentering the West they leave a vacuum, which is why the postmodernist project has all but collapsed. We must search for positive principles of coherence that are realistic and useful for the purpose of this project. Also, Being Different addresses that Western civilization displays a merely synthetic and precarious unity, and this is for reasons that lie deep in its fragmentary cosmology and its insistence on historical revelation as the basis for religious life.

\section{Challenging Panentheism as Western}

Gier relies heavily upon the contention that in developing the philosophy of panentheism, Charles Hartshorne and Alfred North Whitehead provide a basis for substantiating Western claims to having integral (as opposed to synthetic) unity. However, as I shall explain in some detail, Gier's contention ignores the unmistakably Indian origins of the philosophy imported and reformulated as "panentheism" by these Western philosophers. (I should clarify that panentheism-with the middle syllable "en"-refers to a unified concept of the world as God and simultaneously God as transcendent. This conception of God's dual character is central to integral unity in the theistic Dharma systems. God is the unchangeable transcendent; God also constitutes everything that exists, and hence is ever in flux. This concept is not to be confused with "pantheism"- 
without the middle syllable "en"-exemplified by the nature worship that is characteristic of many pagan faiths, the difference being that pantheism lacks the notion of a transcendent God.)

Given the central place accorded to Hartshorne and Whitehead in Gier's arguments, it is important that I provide further evidence that both men borrow heavily from Indian thought, even though they tended to credit only Western thinkers for supplying the building blocks and inspiration for their views. Successive generations of Westerners have turned these ideas into original "Western" thought and washed away their Indian sources to conceal evidence of the appropriation.

Gier states that the German philosopher Karl Christian Friedrich Krause coined the term "panentheism" in 1828. Many Western accounts note this coinage as if it were a wholesale invention, ignoring the fact that Krause was a serious scholar of Sanskrit who employed Sanskrit texts to develop and argue his ideas. These ideas departed from the work of his predecessors J.G. Fichte, F.W.J. Schelling, and Hegel. German historians of nineteenth-century philosophy will know that it was from Sanskrit sources that Krause derived the notion which he eventually introduced into German philosophy as "panentheism." In fact, he influenced Arthur Schopenhauer, who did not know Sanskrit and relied upon Krause for his access to Indian texts; indeed Krause is also said to have introduced Schopenhauer to Indian techniques of meditation. In his article "Eastern Principles within Western Metaphysics: Krause and Schopenhauer's Reception of Indian Philosophy," Claus Dierksmeier sketches "how... [Krause] incorporated some elements of Upanishadic and Vedantic speculation into his system. In particular,...[Dierksmeier] emphasize[s] Krause's 'panentheistic' conception of the absolute being... and how it facilitates an 'open' dialectics that compares favorably with the dialectics of Fichte, Schelling, and Hegel" (2008: 63).

Second, with respect to the question of whether panentheism is indigenous to the West and represents the culminating unification of its various tendencies, Gier says that I am wrong to claim that Hartshorne obtained the idea of panentheism from India. But there is compelling evidence that he derived his view from Indian Vaiṣnava philosophers. This evidence is as follows:

(i) Hartshorne himself acknowledged that panentheism was a concept alien to traditional Christian theology, wherein the notions of monotheism 
and pantheism were considered to be mutually exclusive and exhaustive. For instance, in his Philosophers Speak of God (1953: 1), he introduces panentheism contrasting it with monotheism and pantheism.

(ii) He published several detailed and extensive studies of Indian philosophers and explicitly referred to them as panentheistic thinkers. For instance, in Philosophers Speak of God, on pages 178-79, he refers to Rāmānuja as quasi-panentheist and Jīva Gosvāmī as a full-fledged panentheist. In The Zero Fallacy and Other Essays in Neoclassical Philosophy (1997: 39), Hartshorne speaks of Jĩva Gosvāmī's school anticipating process theology by two centuries. Also, in response to John E. Smith's chapter, "Some Aspects of Hartshorne's Treatment of Anselm" (1984), Hartshorne refers to Jīva Gosvāmī as a panentheist.

(iii) He went on to have contact with later Indian thinkers of the same tradition, especially through Mahanambrata Brahmachari, a Vaiṣnava monk from the lineage of Jīva Gosvāmī. Brahmachari attended the University of Chicago from 1934-37, earning a doctorate in philosophy for a dissertation entitled "The Philosophy of Śrī Jīva Gosvāmī." Hartshorne, who was a professor of philosophy at Chicago (1928-55), worked with Brahmacari over that period. ${ }^{1}$

(iv) Contemporary scholars and theologians, including John C. Plott (1953), Julius J. Lipner (1986), John B. Carman (1994) and Keith Ward (2009), have affirmed without reservation the panentheistic credentials of Rāmānuja.

(v) Panentheism has been a foundational component of many schools of Indian thought, including the Viśiștādvaita philosophy of Rāmānuja, the Gaudịya Vaiṣnavism of Caitanya Mahāprabhu and the diverse traditions of Tantra and Kashmir Śaiva, all of which predate Hartshorne by several centuries.

After studying and writing on Rāmānuja's metaphysical system for many decades, Hartshorne became dissatisfied with what he considered as the "incompleteness" of the Indian philosopher's panentheism, which he attributed to Rāmānuja's failure to fully apply the principle of dipolarity with regard to divine nature. This supposed "shortcoming" should, in fact, be ascribed to Hartshorne's own rigid and forced over-application of Whitehead's dipolarity principle. Neither Rāmānuja nor Jīva Gosvāmī entertained any a priori notion of dipolarity, and neither was constrained by it. These Indian panentheistic thinkers remained free to maintain the 
transcendence-qua-immanence of divinity through the principle of the universe-as-the-body-of-brahman, while also upholding the goodness and accessibility of the Lord (Kṛna). Ultimately, in order to preserve the "goodness" of his own deity, Hartshorne was obliged to compromise his adherence to the dipolarity principle on the question of whether evil is applicable to God. Hartshorne's assimilation of Indian panentheistic concepts is therefore hobbled by the traditional rigidity of Western logical frameworks such as dipolarity, even though dipolarity was itself designed to ameliorate the inflexibility of Christian monotheism.

Gier also states that "the rationalist Hartshorne breaks with Gosvāmī on the question of divine revelation as the primary source of knowledge" (emphasis added). Was Hartshorne a "rationalist" simply because he applied dipolarism to Christianity? To merely superimpose a logical category on a doctrine rooted in revelation does not alter the fundamental dependence of that doctrine upon revelation: a primary determinant of the dogmatic character of Christianity. Regardless of whether the notion of dipolarism is derived from Whitehead or Rāmānuja or Jīva Gosvāmī, the fact remains that such a category fits poorly with the underlying monotheism of Christianity. Any "rationality" ascribed to Hartshorne, or to any Christian theologian by virtue of having employed such a category, must necessarily be superficial; ultimately, their arguments are circular in character and resort to biblical history-centric revelation as the final authority. ${ }^{2}$

In comparison, Jīva Gosvāmī has far more in common with rationalists and empiricists, since he gives priority to experience (anubhüti) and reason (yukti)—rather than to revelation. Whilst Hartshorne's theology is purely theoretical and speculative, lacking reference to any credible practice equivalent to yoga or sādhana, all Dharma systems including that of Jīva Gosvāmī are rooted in direct experience and are therefore open to verification. Rather than Hartshorne, it is Jìva Gosvāmī who ought to be considered a rationalist for his advocacy of reason as a primary means of knowledge and an experientialist-empiricist for having accorded first place to experience in his epistemology. ${ }^{3}$

Thus, Jìva Gosvāmī’s approach is predominantly "rational" because from the triad of valid means of knowledge (pramānna) that Jìva Gosvāmī describes, his epistemology prioritizes experience and reason over revelation. Significantly, śruti, loosely translated as "revelation," is listed third 
in the triad of pramānas, not first. This order of precedence, in itself, renders implausible Gier's contention that Jīva Gosvāmī's theology is derived primarily from revelation. I emphasize this point specifically because the central, even foundational, role of experience and reason in Indian soteriological systems is rarely recognized by Western critics, presumably because it would undermine the myth of "rational West and mythical East." Gier's charge represents a distortion introduced by projecting the Christian theological epistemology of faith and revelation onto Indian philosophy.

Clearly, and contrary to what Gier would have us believe, the debt that Hartshorne's formulation of panentheism owes first to Rāmānuja's Viśișțādvaita and subsequently to Jīva Gosvāmī's Acintya-bhedābhedavedānta is huge. Furthermore, Gier is seriously in error when he states that Hartshorne "was most impressed by Bengali Vaiṣnava theologian Jīva Gosvāmī." It is Rāmānuja, not Jīva Gosvāmī, whose work Hartshorne has publicly admitted to being "impressed by." In fact, while Hartshorne's writings over many decades include extensive analyses of Rāmānuja, they mention Jīva Gosvāmī far less. ${ }^{4}$

\section{Buddhist Origins of Process Philosophy}

Gier's assertion that Western civilization has moved beyond a merely synthetic unity is also heavily based on his reading of Whitehead and on what has come to be called the "constructive postmodernism" of contemporary process philosophers, of which he supposes I am ignorant. But he fails to highlight the relationship between such Western philosophies and Indian schools of thought. A century ago, many Western thinkers were quite open in acknowledging the Indian sources of their ideas; nowadays over the course of successive intellectual movements, this acknowledgment has been lost in the repackaging of Indian ideas into newly invented terms such "process philosophy" and "constructive postmodernism."

Buddhism was very much in vogue in the late Victorian and Edwardian Britain of Whitehead's day, and both he and his pupil, Bertrand Russell, studied it with interest. Whitehead was undeniably impressed and influenced by its ideas. "Buddhism," he once wrote, "is the most colossal example in the history of applied metaphysics" (cited in Verhoeven 2001: 88).

In the heyday of Whitehead's tenure at Cambridge, many leading British 
intellectuals were strongly influenced by Abhidharma philosophy, a hallmark of the Theravāda school of Buddhism. Among such scholars were Thomas and Caroline Rhys Davids, who produced much literature on the subject. As early as 1910, the Pali Text Society published the Compendium of Philosophy, U. Shwe Zan Aung's English translation of Ācariya Anuruddha's Abhidhammattha Sangaha, with an illuminating introductory essay by Caroline Rhys Davids. At Harvard, too, Whitehead's tenure was contemporaneous with the firm establishment of Buddhist studies, which covered the various traditions of Indian and Far Eastern Buddhism (Chinese and Japanese Mahāyāna).

It is not surprising, then, to find extensive correlations between Buddhism and Whitehead's process philosophy. These have been documented at length in a doctoral dissertation by Peter Kakol (2000). I too have worked for over a decade with specialists on Buddhism and on Whitehead to trace the influence of Indian ideas on the philosopher. Table 1 lists the original Sanskrit terms for some key Buddhist concepts, the English equivalents of these terms, and the terms used by Whitehead when mapping these concepts onto his own framework.

What is surprising is the extent to which Whitehead withholds acknowledgment of the influence of these Buddhist concepts, and instead he attributes the origins of his thought only to Western sources. While he makes vague token references to the general affinity his organic philosophy has with "some strains of Indian, or Chinese, thought," he gives no indication of the specific origins of such extensive correlatives as are listed in the table. In contrast, Whitehead routinely cites ancient Greek philosophers such as Heraclitus as proto-proponents of the process view throughout his major work, Process and Philosophy (1929). G.W. Leibniz's Monadology (1714) is mentioned as his inspiration for actual entities, and John Locke is referenced as his model for non-substantialism; yet all the while, his arguments remain patently Buddhist.

Whereas the Western precedents Whitehead cites are weak analogs at best, the Buddhist tenets from which his system derives are clear-cut and immensely detailed. Indeed, it could be demonstrated that Whitehead's arguments are strongest and most lucid when he remains closest to the original Buddhist models (even though he does not acknowledge them). In comparison, his contentions become vague and confusing when he turns to speculation and bouts of "originality" by inventing terminology 
Table 1

\begin{tabular}{|c|c|c|}
\hline \multicolumn{2}{|c|}{ Buddhist Term } & \multirow{2}{*}{ Whitehead's Term } \\
\hline Sanskrit & $\begin{array}{c}\text { English } \\
\text { Approximation }\end{array}$ & \\
\hline anitya & impermanence & \multirow{2}{*}{ process } \\
\hline bhava & becoming & \\
\hline śūnyatā & emptiness & non-essentialism \\
\hline $\begin{array}{l}\text { pratītya- } \\
\text { samutpāda }\end{array}$ & $\begin{array}{l}\text { dependent arising or } \\
\text { relativity }\end{array}$ & relativity, nexus \\
\hline samaya & occasion & $\begin{array}{l}\text { occasions of experience, } \\
\text { or actual occasions, or } \\
\text { actual entities }\end{array}$ \\
\hline mātrkā & matrices & speculative scheme \\
\hline trikāla-sat & $\begin{array}{l}\text { existence in the three } \\
\text { times }\end{array}$ & objective immortality \\
\hline skandha & aggregate & concrescence \\
\hline avidy $\bar{a}$ & ignorance & $\begin{array}{l}\text { fallacy of misplaced } \\
\text { concreteness }\end{array}$ \\
\hline vedanā & feeling & feeling \\
\hline svalakṣaṇa & thing-in-itself & actual entity \\
\hline prāpti & $\begin{array}{l}\text { propinquity or } \\
\text { pressing }\end{array}$ & prehension \\
\hline paramārtha & $\begin{array}{l}\text { ultimate realty, or } \\
\text { final meaning, or } \\
\text { ultimate thing }\end{array}$ & final reality, res verae \\
\hline patṭhāna & relations & nexus \\
\hline
\end{tabular}

and framework, and when he attempts to formulate his arguments into a general "theory of feeling" that is unsubstantiated by any experiential grounding on his part.

Neither Heraclitus, Leibniz, Locke, Whitehead, nor any of the others in this "imagined" Western lineage claim to have tested, or used as an experiential source, any rigorous system of meditation with the exactitude and 
continuity characteristic of Dharma traditions. Whitehead's construction, then, partially amounts to a collage of ideas "cut and pasted" from Buddhism; it represents a purely synthetic unity of thought that cannot be considered primary and that certainly never supersedes Buddhism in any significant respect. Anyone with a genuine knowledge of Buddhism would find Whitehead's attempts to claim Western philosophers as his sole theoretical predecessors entirely unconvincing.

\section{Is the West Synthetic?}

In the course of his argument that Western civilization is not synthetic, Gier also takes exception to my critique that the West conquered other civilizations through violence and then seized and synthesized selective items from their cultures. He cites violence committed by Tibetan Buddhists to make his case in reverse. But the worldview of Tibetan Buddhism did not originate as a result of armies bringing back intellectual property from conquered peoples. Hence the Western and Tibetan instances of violence cannot be equated. The same applies to his examples of intense debates among various Dharma schools: he equates Indian debates with European military invasions of far-flung continents thousands of miles away from home!

Before concluding this section, I would like to point out the extent to which illogical statements are marshaled in order to block the acknowledgment of Indian influences upon the West. Being Different mentions the Sri Lankan Buddhist scholar Anagarika Dharmapala in the context of noting that William James was influenced by several dharmic sources including Svāmi Vivekānanda and Dharmapala (p.95). Gier writes: "It is ironic that Malhotra praises Dharmapala, since the latter joined Colonel Henry Steele Olcott in promoting 'Protestant' Buddhism that fueled Sri Lankan nationalism and religious fundamentalism." Gier confuses observation with praise. My statement is not an appraisal of Dharmapala's personal ethics, but about India's influence on the formulation of Western psychology via various intermediaries like Dharmapala. That James was influenced by Dharmapala as a source of Buddhist knowledge is not undermined by Dharmapala's character as a Sri Lankan nationalist or religious fundamentalist. By way of analogy, it is well known that Nazi rocket science influenced NASA after World War Two, but this influence 
cannot be denied by citing the horrors of Nazism. Whether $\mathrm{X}$ influenced $\mathrm{Y}$ is not resolved by discussing the ethics of $\mathrm{X}$.

\section{The Politics of Coherence and Incoherence}

Recently, I was invited to the âsrama of a prominent Hindu guru in the U.S., where an American professor of Hinduism was explaining what she considered to be biases against Hinduism in a popular American school textbook. The chapter on Hinduism featured impressive pictures of all sorts of symbols, deities and rituals, and contained factually accurate descriptions of a random assortment of elements associated with Hinduism. The professor could not pin down any specific incorrect statement in the chapter, yet it failed to convey any clear sense of what Hinduism actually meant. It would leave a student with sensory overload and an impression of Hinduism as being incoherent. In contrast, the chapters on all the other major religions started out by establishing coherent ideas of how those religions saw themselves followed by details presented in an organized manner. The bias against Hinduism was subtle but deep.

This incident sharpened my insight into the crux of the problem I confront in Being Different. It helped me identify the key questions upon which the present debate centers: Is Hinduism (and Dharma in general) incoherent? Or is it in fact coherent? If it is coherent, is it of a positive kind that offers something of value to humanity, or is it a scourge of abusive practices that ought to be erased by importing "Western progress"?

\section{Charge of Incoherence}

Implicit in Larson's essay is a view common among many Western scholars (and in some cases it appears to be followed almost unconsciously) that Dharma, and in particular Hinduism, lacks coherence of any worthy kind. Accordingly, Dharma can at best be "appreciated" as a mishmash of disparate, contradictory and mutually irreconcilable ideas and practices. Sociologists and anthropologists focus upon conflicts and oppression in modern Indian society and project their findings onto ancient Indian texts to show that incoherence has always been an essential characteristic of India. Even those scholars of religion who might otherwise show appreciation of Hinduism often portray it as an exotic and unintelligible collec- 
tion of peculiar practices and strange problems, reminiscent of other primitive societies that were superseded by the West.

Chapter 4 of Being Different summarizes various Western imaginings of a "chaotic India" to illustrate this mindset and offers a critical Indian response by reversing the gaze upon the West's fixation with "order." The view through the Western lens has several important consequences:

(i) Through its assumption of a lack of internal consistency and unity of Dharma, the West is able to undermine any claim made on behalf of Dharma civilization. Any attempt to speak of such an entity in positive terms can be debunked by asking, "Which 'Dharma' are you referring to?," and thereby characterizing any attempt to establish coherence as being flawed, chauvinistic or even dangerous.

(ii) Coherent theories of India and its civilization are often dismissed by falsely alleging that any such claim must necessarily imply an imposition of homogeneity. Larson makes this very allegation, but fails to acknowledge that Being Different repeatedly explains how the notion of unity in Dharma is based on internal diversity and not on internal homogeneity. As a corollary to the Western denial of a coherent foundation common across Indian schools of thought, there is the conclusion that Indians ought to simply deny themselves any unified positive identity based on their own past and must instead seek a common identity based on importing modern Western principles to an even greater extent than they already have. (The reader may note that this is hardly distinguishable from the "civilizing mission" of colonialism.) The very notion of a classical Indian civilization is seen as a disease, and the Western scholar is presented as a physician to cure Indians from it.

(iii) My earlier book, Breaking India: Western Interventions in Dravidian and Dalit Faultlines (Malhotra and Neelakandan 2011), shows how such discourse on the fragmentation of India has been used to stir up internal divisiveness and conflict-ironically, in the name of "human rights." (The jury is still out on whether attempts to impose Western universalism upon Islamic nations will empower their citizenry with human rights or simply destroy them through the incitement of infighting, while positioning the West to better control their natural resources.)

(iv) Those few individuals who articulate Indian coherence must, therefore, be characterized as dangerous people by smearing them with allegations of fascism, identity politics and links to atrocities; or at the 
very least, by tagging them with nonsensical labels such as "Brāhmanical Neo-Hindus" as Larson does.

(v) The characterization of Dharma as incoherent serves to protect Western hegemony. As noted earlier, the intellectual sophistication of Dharma offers a vantage point from which to decenter the West and its claim of universalism. Since this would pose a grave threat to Western universalism, it becomes important to undermine the legitimacy of Dharma as a coherent position from which to gaze upon the West.

\section{Digesting "Incoherent" India into the "Coherent" West}

The argument of incoherence is used to justify the fragmentation and repackaging of Dharma so that it becomes a kind of "spiritual delicatessen": a buffet of disparate notions, from which Westerners can pick, choose and digest individual elements for their own purposes. In this regard, a major focus of my research is to document the variety of Western appropriations from Dharma that become reformulated (without attribution) into Judaism, Christianity, and Western science. Enterprising new "pioneers of Western thought" can claim this digested Indian knowledge as the product of their original discoveries; subsequently, the Indian sources are erased and replaced with Western substitutes. I have written a series of case studies documenting such a process of digestion, in disciplines ranging across philosophy of science, religion, linguistics, arts, medicine, botany, neurosciences, healing paradigms and more. While many such digestions have merit because they can enhance old ideas, many others cause distortions and limit the potential for Dharma to play its part on the world stage. In an effort to boost their own status, scholars who serve as the facilitators of digestion typically map dharmic contributions onto the limited frameworks of Judeo-Christianity.

One of my reasons for writing Being Different was to sharpen our understanding of the differences between civilizational frameworks which the digestive transfers of knowledge typically fail to protect. I have pointed out the sleight-of-hand nature of many digestions, such as the frenzied efforts to develop and repackage ideas of Dharma into "Wilber's Integral Theory," "Non-dual/Integral Christianity," "Integral Judaism," feminine divinities in Western religions, sacredness of the earth, Christian Yoga, and the like. Larson's arguments that Dharma is "incoherent" serve to divert attention away from this massive intellectual plunder by 
the West. My project has been to constantly remind the "pioneers" behind these acts of digestion of their appropriations, misappropriations, and occasionally blatant plagiarism. The articulation of difference serves as a starting point in many such conversations.

At this juncture I wish to contrast Western appropriations from Greece with those from India. The modern conception of Western civilization includes Greece as a subset, making it unnecessary for Western scholars to replace Hellenistic sources with other Western substitutes. Hellenistic sources have retained their identity and distinctiveness. When modern Western scholars treat those thinkers as source material, they receive proper attribution.

In contrast, India remains in Western eyes the non-Western other; India is too different, too far away, and too massive to be included intact within the West. The inclusion of a unified India in the Western self-conception would threaten the very sense of what it means to be "Western." Therefore, what India offers must be broken into smaller parts that can be separately consumed and digested. For this to become possible, the coherence of India must be undermined, by emphasizing its fragmentation and incoherence.

This intellectual breakup of India is akin to a predator's breaking up of its prey into morsels that lend themselves to digestion. It would not be feasible to swallow a large prey whole within the predator's body. Instead, it must be cut into parts, and as it passes through the predator's digestive system it must be further broken systematically, until every last protein and nucleic acid molecule has been processed by enzymes to yield rawmaterial as nutrients for the predator's growth. Ultimately, no trace remains of the prey's own DNA; meanwhile, the raw-material nutrients produced by digestion are reassembled into the predator's cells, under the control of the predator's DNA.

The appropriation and absorption of non-Western sources into the West proceeds by a similar kind of digestive process, so that the West may retain its sense of selfhood while capturing whatever aspects of India it seeks to own. This is why the mainstream Western academy does not teach Abhinavagupta, Bharata, Bharț̣hari, Śan̉kara, Kālidāsa, Kāpila, Kauțilya, Nāgārjuna, Pāṇini, Patañjali, Rāmānuja, and other Indian greats on par with the great Greek thinkers. This double standard contradicts the idea of a truly "flat world," wherein classical thinkers of all civilizations 
would be incorporated into curricula based on their merit and current relevance.

Just as the individual ego is the nexus of one's narrative about oneself, so also a peoples' collective ego centers upon its shared coherent narrative. The West's expansive collective self ascribes a teleological role to its own coherence. Because it finds itself coherent and views the other as incoherent, it seeks to digest the source of that perceived incoherence by breaking it into fragments and selectively mapping some of those fragments onto its own framework. Whatever it discards ends up being ejected as the waste product of the digestion process. This is why the act of bolstering one's own coherence, while undermining the coherence of others, is so central to the game of civilizational aggression.

Despite the fond hopes of postmodernism, the competition between collective identities is not fading away; rather, it is actively intensifying, as the global demand for material things outstrips their supply. In Being Different, I point out that postmodern thought has influenced the Indian elites to view their own heritage as incoherent and further to imagine that all other nations are also blurring their identities to the same extent. They do not realize that the postmodern deconstruction of grand narratives has been vastly asymmetrical with respect to its effects on the West and the non-West. This is why Being Different stands clear of the infinitely regressive trap of postmodern nihilism; it does not permit outlying exceptions to negate the overwhelming salience of characteristic features in either Dharma or Western civilization. Studies that avoid the categories of Dharma or the West invariably fall into this trap, crippling any further efforts to understand the intended objects of their gaze, and ultimately reinforcing the status quo of Western domination.

\section{Larson's Theory of India's Incoherence}

To illustrate the syndrome wherein many Western scholars want to emphasize India's incoherence, I shall refer to Larson's 1995 book, India's Agony Over Religion, in which he takes a stand on the issue of continuity and coherence in Indian civilization. He writes:

Whatever continuity one finds in Indian history and culture is directly related to India's basic discontinuities. Another way of putting the same point is to say that there is nothing like an abstract "essence" of 
Indian civilization. There are, to be sure, distinctive cultural presuppositions operating in each of the six historical periods (the Indus Valley, the Indo-Brāhamṇical, the Indo-Śramaṇical, the Indic, the Indo-Islamic and the Indo-Anglian) that we have examined. But there are no common features or presuppositions that hold overall. What emerges, instead, by way of continuity is a certain distinctive kind of on-going conversation or cluster of conversations about the salience of certain diverse, even contradictory, cultural values and who or what are the basic warrants or authorities for those cultural values.... The coherence, however, is not to be found in the specific contents of a given historical period or the authoritative utterances of this or that particular group (Larson 2005: 142-43).

Earlier in the same book, he lays the foundation for his theory of Indian civilization as a series of discontinuous "layers," and further alleges that each such layer has foreign origins:

It should be noted that in an important sense one can plausibly argue that all of the layers come from the 'outside,' as it were, that is to say, the layers are not indigenous to the subcontinent. This is obviously true for layers (2) through (4) (53).

On the same page, he defines layers 2, 3, and 4 as Indo-Brāhmanical (c. 1500-600 BCE), Indo-Śramanical (c. 600 BCE-300 CE), and Indic (Hindu-Buddhist-Jain) (c. 300-1200), respectively.

Larson is very clear that Sanskrit and Dharma derive from foreign "Āryan" origins, as illustrated in his following passage:

What is reasonably clear is that some time in the early part of the second millennium (just after c. $2000 \mathrm{BCE}$ ), semi-nomadic warrior tribes who had been living in the steppeland that ranges from Eastern Europe to Central Asia began to undergo extensive migrations.... The tribes conquered local people as they moved, inter-married with the indigenous population and developed into a ruling elite. They were known as Ārya-s or Āryan-s (meaning 'noble ones'), and those Āryan tribes that reached Persia and India are known as Indo-Iranians or Indo-Āryans.... These Indo-Āryan nomadic tribes brought with them into India in the 
middle of the second millennium (c. 1500 BCE) a number of cultural characteristics that were to prove determinative for the development of later India civilization... (58).

He goes on to state that these foreign "Āryans" brought with them several elements of dharmic culture: the Sanskrit language, the patrilineal system of social hierarchy that became the caste system, the practice of conducting elaborate sacrificial rituals involving hallucinogenic substances called soma, and an entire pantheon of imported gods. He does not attempt to defend this view of history; he simply assumes its complete validity, including the dates he ascribes to these supposed "layers" of Indian civilization and his contention that each "layer" originated outside India; and he makes no effort even to support his assertion that these "layers" are discontinuous and in conflict with one another. In fact, his assumptions about Indian history, which premise his entire thesis of an internal conflict within Dharma, amount to no more than a reformulation of old colonial Indology: itself a shaky edifice that is now much questioned.

I appreciated certain aspects of Larson's book when I read it in the 1990s. Still, I could not help noticing that he clearly chose not to examine Christian claims from a Hindu perspective. Even when he explains Indian coherence in terms of karma, he stops short of using the perspective afforded by a karma-based worldview to reverse the gaze at Christianity. Had he proceeded in that direction, he might have better appreciated chapter 2 of Being Different, which uses the postulates of dharma (including karma and reincarnation) to examine the notions of Original Sin, Virgin Birth, Crucifixion, Redemption, and the End Times. Considering how central these notions have been to the Nicene Creed, and hence to Christianity, it is most unfortunate that he eschews such comparisons. His evident discomfort with Being Different may well reflect his realization of where such a path of gaze reversal might lead.

It is not surprising, then, that Larson promotes imported solutions to bring coherence to India. In his essay in this issue, he lists some Indian thinkers who, evidently, serve as his role models for scholarship on Indian civilization. "Only the "solution of synthesis'," he writes, "was able to prevail" in their works. He highlights what he characterizes as the irreconcilable but fascinating "differences" among various Indic traditions and proposes that unifying solutions must be derived primarily 
from India's interactions with the West. He goes on to advocate the approaches of Amartya Sen and V.S. Naipaul, even though it is well known that they lack adequate grounding in classical Indian traditions and are largely influenced by Western universalism. Their critique of the West tends to be largely the West's own self-critique replicated through brown-skinned luminaries. In the matter of bringing coherence to India, Larson's solution is clearly imported.

Larson says that I have allowed myself "to get caught up in what might be called the self-referential problem (sometimes also called the 'selfreferential paradox')." He implies that I can be accused of the very thing I charge others with: namely, that I am "digesting" the dharmic traditions into one monolithic and forced whole. By the same token, he himself falls victim to this very paradox by insisting upon seeing the four Dharma traditions of Hinduism, Buddhism, Jainism, and Sikhism as disparate enough to defy categorization under a single umbrella or family; which is clearly a stance characteristic of his training as a Christian minister to look upon these entities through the lens of "religion." Given the nature of Abrahamic religions, it is unconsciously assumed by many scholars that a faith must be principally defined by the most history-centric (and hence, the most exclusivist) of its precepts. This unfortunate assumption blinds Larson to the existence of a shared sanskrti of culture and categories underlying all four of the Dharma traditions. A great many of the errors made by the authors of the essays in this issue, and by my critics elsewhere, have been the result of examining Dharma in terms of the two essentially separate Western categories of "religion" and "ethics," and thereby declaring Dharma deficient on both counts. ${ }^{5}$

\section{Some Further Points}

\section{History Centrism: The Elephant in the Room}

Unfortunately, Yelle, Larson and Gier do not directly comment on my history centrism theory and my claim that this is a major characteristic differentiating the Abrahamic and dharmic traditions. Yelle tries to discredit a few of the examples I have used, even though none of these examples is central to the theory itself. For instance:

(i) Being Different mentions how history centrism shaped the clash between Christian Zionism and Islam over the Dome of the Rock. Yelle 
writes that upon reading this, his "jaw literally dropped. It is not possible that Malhotra is unaware of the destruction of Babri Masjid by Hindutva radicals at Ayodhya in 1992." In response to him, I do regard the posture of certain Hindus towards Ayodhya as an attempt to turn Dharma into a history centrism version-the "Westernization" of Hinduism; and this serves to illustrate that my notion of history centrism has broad application. That being said, the degree to which history centrism has prevailed upon Hinduism is far less than in the case of Abrahamic religions. Dharma's central qualities have not been shaped by it, unlike the Abrahamic religions, where God's separation from humans makes the prophetic lineages the only means through which those religions have received their core texts. Canons are essentially history textbooks. Yelle misses a good opportunity to use history centrism and argue against those strains of Hinduism which seek to remake it in the image of Western religions.

(ii) Another illustration of history centrism in Being Different is that the history centric events that took place in the Garden of Eden have often meant that the body is seen as sinful, a view accepted by many respectable theologians and major churches. Yelle's rejoinder is that I neglect "the parallel with ancient traditions of asceticism and celibacy in India." But this misses the point: Indian celibacy/asceticism is not based on a singular history centric event equivalent to the Fall in Eden. Indeed, there are many similar features in both cultures, but they do not result from the same axioms. I am comparing the underlying axioms.

(iii) Yelle takes exception to Being Different's explanation of the importance given to bloodlines ever since the Old Testament. He writes: "Within the Church itself, arguably the notion of 'race' did not emerge until the blood purity laws (limpieza de sangre) toward the end of the Reconquista in Spain; that is to say, they were part of an internal colonialism linked to a new, external colonialism." However, the issue here is not racial purity in the modern sense that Yelle uses, but rather the passing along of the religious lineage along ethnic lines. I do not think any Old Testament scholar would disagree that this is a major preoccupation of the ancient Israelites.

Gier, too, fails to acknowledge the book's central idea of history centrism, even though it is stated very explicitly as the basis for my contrasts. He tries to refute the idea that Christian history gives far greater theolo- 
gical importance to its martyrs than Dharma does, by claiming that martyrdom existed in India in a comparable manner. He cites that millions of Indians were killed by Muslims and that various other individuals such as Gandhi died as martyrs. Of course, in the history of every nation and people there are numerous examples of individuals who have been killed on religious grounds, but my intention was to highlight the importance given by Christian military expansion to honoring martyrs in God's name and to encouraging martyrdom explicitly as a religious act. While many people were made Christian saints specifically for their martyrdom, the criteria for achieving greatness as a yogī or a rssi or a guru is not met by getting killed in military action. The theological difference here is that unlike living jīvanmuktas or living nirvānas, Christians must be dead before they can be elevated to sainthood. This difference cannot be glossed over by merely citing that there is killing in all religions.

\section{Intellectual Elitism}

Another charge I wish to address, stated directly by Larson but also alluded to by others, is that some of the ideas I use to characterize Dharma were propounded by elite thinkers (the "neo-Brahmins") who, according to Larson, comprise a mere 3.5 percent of the Indian population. Were we to apply this same criterion to test the validity of prominent Western ideas, we would also have to confront the fact that only a tiny fraction of one percent of all Christians have been theologians who made any kind of impact upon Christianity; indeed, that a miniscule percent of Westerners have been sufficiently gifted to formulate the ideas which significantly influenced the course of Western science or philosophy. One does not question the legitimacy of theoretical physics, for instance, based on the fact that an extremely tiny percent of the general population has participated in formulating its precepts. In any society, and regardless of culture or discipline, it is only a small fraction of thinkers who nucleate longterm change and who are equipped to propose the concepts that wider segments of the population may eventually absorb and institutionalize through a process of selection. Larson needs better arguments than this to support his criticisms.

\section{Dharma and Physics}

Gier is troubled that I cite several prominent modern physicists whose 
ideas were inspired by Hinduism and/or Buddhism. I tend to agree with Gier that most such scientists had limited knowledge of Indian philosophy, but nothing in Being Different relies upon the correctness or extent of their ideas of Indian philosophy. It is their understanding of the philosophy of physics that I am discussing. Gier says that he "side[s] with Stapp's idea" on quantum mechanics, and in response I wish to point out that I knew Henry Stapp in the 1990s and that before he wrote his seminal book, Mind, Matter and Quantum Mechanics, he had extensively studied the Vaisnava interpretation of quantum mechanics with the help of Vaiṣnava scholars in California and Mumbai. His research was published as A Report on the Gaudiya Vaishnava Vedanta Form of Vedic Ontology (1994), in which he explains that Gauḍiya Vaiṣnava Vedānta provides an internally consistent and complete interpretation of quantum phenomena whereas Western thought at that time did not. He was not alone in this assessment among Western scientists till the 1990s, and only years later were these ideas gradually digested into Western frameworks and the original Indian sources faded into oblivion.

Gier brings into his analysis various Western theorists who borrowed heavily from Indian sources when he writes that "contemporary physics does not support the idea that the universe is a cosmic mind, and both theory and empirical data point to a radical pluralism of discrete entities rather than an undifferentiated divine entity." First of all, I have already clarified in this essay that my position has never been to support an "undifferentiated divine entity." Second, even if we assume that his position reflects an adequate knowledge of physics, it makes no difference to my thesis-which is about Indian influences, regardless of whether or not a given Western borrower was accurate in his borrowing. An inaccurate borrowing is also an influence, and in fact, many influences travel in this manner.

\section{Lack of Mutual Respect Outside the Academy}

To illustrate the problems with current interfaith debates, one of the examples cited in Being Different is an event that took place at Claremont Graduate University. Representatives of various religions who attended this event had prepared a resolution to "tolerate" each other, and I suggested that this be replaced by the term "mutual respect." Gier assigns great importance to the Claremont reference, and his refutation of my 
position is rather strange. It hinges on one theologian, John B. Cobb, at Claremont. Gier goes on to describe the curriculum at Claremont and various other details, none of which have any relevance to the point at hand. My criticism does not apply to Claremont as an institution, or to Cobb, or any other member of its faculty. The fact that Claremont held such an event does not mean that all the speakers would reflect the positions held by one or more Claremont scholars-after all, it was an interfaith event with speakers unaffiliated with the university. Gier's view is one seen from an Ivory Tower; that is to say, he seems to think that a few scholars on campus are representative of society at large.

\section{Chaos}

Regarding Being Different's examination of the position given in Hinduism to what Westerners call "chaos," Yelle finds it compelling that Victor Turner's 1977 work on "structure versus anti-structure, liminality, and communitas" shows the same to be true of the West. The Carnival in Roman Catholicism is cited as an example of similar stances with regard to chaos. But this example is not biblical and is most likely the result of absorption ("digestion") of pre-Christian paganism from Greece, Rome, and elsewhere. In any case, Being Different's extensive treatment of the nature of "chaos" in Hindu narratives, cosmology, and philosophy cannot be trivialized by a comparison to modern Catholic pop culture. Being Different cites American research on the U.S. government's suspicion of India during the Cold War, because it saw India's polytheism, paganism, millions of gods and chaos in general as indicators that it was an unreliable ally. By contrast, the U.S. government sources cited in the declassified U.S. documents regarded monotheistic Pakistan as more certain about its idea of truth and thus more stable. Yelle misses the implication of this point when he writes: "[Malhotra] blames communalist ideologies and the associated violence in the subcontinent on the ill effects of an exclusivist ideology imported from monotheistic traditions and as alien to Indian pluralism." My book is not on the subject of subcontinental violence.

\section{Islam}

Gross is right in pointing out the obvious omission of Islam from Being Different. In an earlier draft I sought to include Islam in my analysis, but 
found that I could not do the complexities justice. While Islam is an Abrahamic religion and subject to much of what I say about them, it is also very different from Judaism and Christianity and hence it warrants a separate treatment.

\section{Caste}

I also readily admit to the absence of any elaborate treatment of caste. Being Different mentions that traditionally varna-dharma was diverse, contextual, flexible and flowing. Ironically, Yelle opposes my non-essentialist approach to caste and would like to see it essentialized. All of a sudden his talk of heterogeneity of views and cultures seems to disappear. $\mathrm{He}$ is troubled by my statement that "different communities within the same society were allowed to practice their own codes," even though this resists homogeneity. Furthermore, Yelle fails to substantiate his position that caste was a matter of "external imposition" and does not give a shred of evidence that any "external" institution "imposed" it. To the best of my knowledge, there was never a central church-like institution to impose it.

Overall, Yelle and Larson are correct in observing that Being Different does not emphasize caste discrimination, communal violence, and so forth as a central theme. These issues have been discussed across a wide range of forums, and I myself have addressed them elsewhere. The purpose of Being Different, however, is to de-center Western universalism. Cluttering this particular text with scripted tropes of little or no relevance would only have diverted attention from its primary purpose of reversing the gaze upon the West. The issue of caste would lead to a debate about the social stratification and oppression in each civilization, and the extent to which each system of bias is philosophically rooted as opposed to being the result of historical events. Caste is a separate topic in itself. It does not lead to comparisons of the philosophical axioms that Being Different wants to uncover, because caste is not a philosophical axiom in Dharma ontology or epistemology.

\section{Concluding Thoughts}

I wish to clarify here that I am not opposed to cross-fertilization among cultures. On the contrary, I favor such transactions while remaining 
mindful of the ethics involved and exploring their implications for the sustainability of civilizational diversity. Furthermore, I do not wish to deny the important contributions made by Western thinkers to philosophies that resemble Indian thought. What Being Different takes exception to is the fact that Indian sources get sidelined and replaced by Western ones with retroactive effect; that is, through the dubious backward projection of knowledge borrowed from Indian sources onto supposed Western equivalents of antiquity. Being Different's sections titled "Digestion and Assimilation" (36-38) and "The Templeton Project to Re-invent the West" (141-44) discuss this syndrome in explicit detail, demonstrating how it leads to distorted accounts of both civilizations.

The West should harvest the fruits of Indian knowledge, by all means; however, it must also nurture and respect the roots of the tree that bore them. This would entail developing a stance conducive to genuine and sustainable coexistence with other civilizations; one that is premised upon a relationship between equals who offer one another mutual respect for whatever differences exist between them. Contrary to the wishful thinking of many sheltered liberal arts academicians, such a desirable shift in Western attitudes is not currently on the horizon.

\section{Notes}

1. Brahmachari spent six years in the USA, from 1933 to 1939. In 1933, he was appointed international Secretary of the World Fellowship and set out on a lecture tour of 63 American cities. He delivered 345 addresses and was a guest in 29 universities and colleges. Thomas Merton was one of many prominent theologians who paid tribute to Brahmachari.

2. For an incisive critique of the Christian theologians' claims to "rationality" see Dharmasiri (1988).

3. Gier might be more correct in characterizing Hartshorne as a "rationalist" if that term referred specifically to Hartshorne's reliance upon the Hegelian-Kantian a priori procedure of deductive reasoning.

4. The fact, however, is that Hartshorne did borrow extensively from Jīva Gosvāmī, but did not want to admit this.

5. See pages 259-63 in Being Different for a concise explanation of the difference between Dharma and religion, and pages 191-203 for an explanation of the contextual nature of Dharma. 


\section{References Cited}

Bhajananda, Svāmi. 2010. "Four Basic Principles of Advaita Vedanta." http://www.vedanta.gr/wp-content/uploads/2012/03/SwBhajan_4Basic PrincAdvVed_ENA4.pdf.

Carman, John B. 1994. Majesty and Meekness: A Comparative Study of Contrast and Harmony in the Concept of God. Grand Rapids: William B. Erdmans.

Dharmasiri, Gunapala. 1988. Buddhist Critique of the Christian Concept of God. Antioch: Golden Leaves Press.

Dierksmeier, Claus. 2008. "Eastern Principles within Western Metaphysics: Krause and Schopenhauer's Reception of Indian Philosophy." In F. Ochieng'-Odhiambo, Roxanne Burton, and Ed Brandon, eds., Conversations in Philosophy: Crossing the Boundaries, 63-73. Newcastle upon Tyne: Cambridge Scholars Publishers.

Hartshorne, Charles. 1997. The Zero Fallacy and Other Essays in Neoclassical Philosophy (ed. Mohammad Valady). Chicago: Open Court, 1997.

Hartshorne, Charles and William L. Reese, eds. 1953. Philosophers Speak of God. Chicago: University of Chicago Press.

Kakol, Peter. 2000. "Emptiness and becoming: Integrating Madhyamika Buddhism and Process Philosophy." Ph.D Dissertation in the School of Social Inquiry. Geelong: Deakin University Library.

Larson, Gerald James. 1995. India's Agony Over Religion. Albany: State University of New York Press.

Lipner, Julius J. 1986. The Face of Truth: A Study of Meaning and Metaphysics in the Vedāntic Theology of Rāmānuja. Albany: State University of New York Press.

Malhotra, Rajiv. 2012. Being Different: An Indian Challenge to Western Universalism. New Delhi: HarperCollins.

Malhotra, Rajiv and Aravindan Neelakandan. 2011. Breaking India: Western Interventions in Dravidian and Dalit Faultlines. New Delhi: Amaryllis.

Plott, John C. 1954. "Rāmānuja as Panentheist." Journal of the Annamalai University (Chidambaram, India) 18: 65-76.

Smith, John E. 1984. "Some Aspects of Hartshorne's Treatment of Anselm." In John B. Cobb and Franklin I. Gamwell, eds., Existence 
and Actuality: Conversations with Charles Hartshorne, 103-9. Chicago: University of Chicago Press.

Southworth, Kristen L. 2010. "Hindu Worldview and Ecological Engagement." http://www.breathofstatues.com/uploads/Hinduism_and_Ecology. pdf.

Stapp, Henry P. 1994. A Report on the Gaudiya Vaishnava Vedanta Form of Vedic Ontology, Mumbai: The Bhaktivedanta Institute.

Verhoeven, Marin, J. 2001. "Buddhism and Science: Probing the Boundaries of Faith and Reason" Religion East and West 1 (June): 77-97.

Ward, Keith. 2009. "Hindu Understandings of God 2: The Theology of Ramanuja." http://www.ochs.org.uk/lectures/by-name-sorter/Professor\% 20Keith\%20Ward.

RAJIV MALHOTRA is an independent scholar based in Princeton, New Jersey.

rajivmalhotra2007@gmail.com

Open Access This article is distributed under the terms of the Creative Commons Attribution Noncommercial License which permits any noncommercial use, distribution, and reproduction in any medium, provided the original author(s) and source are credited. 